\title{
Crystallization of octahedral iodide of potassium
}

\section{Bouchardat}

To cite this article: M. Bouchardat (1843) Crystallization of octahedral iodide of potassium, Philosophical Magazine Series 3, 23:152, 317-317, DOI: 10.1080/14786444308644737

To link to this article: http://dx.doi.org/10.1080/14786444308644737

册 Published online: 30 Apr 2009.

Submit your article to this journal 준

Џll Article views: 2

Q View related articles $₫$ 
west, and a much larger circle, well-defined, of a pale white, having the sun in the south-west of its circumference.

The interior of the halo, except the sun's disc, was of a much darker colour than the surrounding atmosphere.

The centre of the larger halo was very near, if not in the zenith.

\section{CRYSTALLIZATION OF OCTAHEvRAL IODIDE OF POTASSIUM. BY M. HOUCHARDAT.}

By evaporating a saline solution containing iodine, iodide of potassium and acetic æether, M. Bouchardat obtained light yellowcoloured semitransparent octahedral crystals. These crystals, when heated in a tube, yielded traces of iodine, and the fused residue consisted entirely of iodide of potassium; similar crystals were produced from a solution of biniodide of potassium by spontaneous evaporation; in order to obtain them there must be a great excess of iodine in the solution, although they do not contain 1-1000dth of their weight of free iodine; but it is certainly curious to observe the iodide of potassium lose its usual form owing to the presence of so small and indefinite a portion of iodine.-Journal de Pharm. et de Chim., Juillet 1843.

\section{ON THE PRESENCE OF THE SULPHATE OF TIN IN THE SUL- PHURIC ACID OF COMMERCE. BY M. DUPASQUIER.}

It is generally known that the sulphuric acids of commerce contain lead, iron, and frequently arsenic; but I am not aware that the existence of tin in them has hitherto been noticed. Nevertheless this metal may be obtained, and in somewhat considerable quantity, from most of the commercial acids; and it will not be useless to be aware of this circumstance, which may have some influence in many operations, especially in those of dyeing, which should be taken into consideration.

I found sulphate of tin in all the acids which I examined while engaged in the researches which $I$ have published on the arseniferous sulphuric acids in the following manner:-In order to precipitate the arsenic of these acids, I diluted them with twice or six times their weight of water, and passed a current of sulphuretted hydrogen through them, which gave rise to a yellowish-brown precipitate when the acid contained arsenic; this precipitate was less considerable, and of a darker brown when the acid was not arseniferous.

Thinking that sulphuret of lead might have been formed, and that the brown colouring of the sulphuret of arsenic should be attributed to that compound, I treated the precipitates obtained by the action of sulphuretted hydrogen on the sulphuric acids with nitric acid, and I constantly obtained a white residue, insoluble in water, soluble in aqua regia, which solution presented all the characters of the nitro-muriate of tin. With respect to the solution effected by the nitric acid, I found it to be arsenic acid when this sulphuret of tin 